\title{
Opening the Door to Complementary and Alternative Medicine: Self-Regulation in Ontario
}

Joan M. Gilmour

Osgoode Hall Law School of York University, jgilmour@osgoode.yorku.ca

Merrijoy Kelner

Beverly Wellman

Source Publication:

Law and Policy. Volume 24, Number 2 (2002), p. 149-174.

Follow this and additional works at: https://digitalcommons.osgoode.yorku.ca/scholarly_works c) (1) $(9)$

This work is licensed under a Creative Commons Attribution-Noncommercial-No Derivative Works 4.0 License.

\section{Recommended Citation}

Gilmour, Joan M., Merrijoy Kelner, and Beverly Wellman. "Opening the Door to Complementary and Alternative Medicine: Self-Regulation in Ontario." Law and Policy 24.2 (2002): 149-174.

This Article is brought to you for free and open access by the Faculty Scholarship at Osgoode Digital Commons. It has been accepted for inclusion in Articles \& Book Chapters by an authorized administrator of Osgoode Digital Commons. 


\title{
Technologies of Risk? Regulating Online
}

\section{Investing in Canada*}

\author{
MARY CONDON
}

This paper places the development of regulatory strategies dealing with the growth of online investing in Canada in the context of theoretical debates about governance through risk. It examines aspects of this emerging regulation relating to (i) use of the Internet by issuers for document delivery; (ii) application of investment suitability rules to online trading; (iii) emergence of new electronic- trading markets. These regulatory developments are considered in terms of the extent to which they exhibit features suggesting: (a) an increased decentring of the state; (b) a shift to risk governance as an end of regulating. The paper argues for the need to pay careful attention to the politics of decentring and risk governance in assessing the emerging regulation ofonline investing.

\section{INTRODUCTION}

Online investing is arguably the quintessential "new economy" activity, involving as it does the marriage of information and technology in pursuit of what Castells calls “informational capitalism” (Castells 2000: 161). While

\footnotetext{
* Thanks to Dimity Kingsford Smith, Caroline Bradley, Colin Scott, Sol Picciotto, and anonymous reviewers for their comments.

Address correspondence to Mary Condon, Osgoode Hall Law School, York University, 4700 Keele Street, Toronto, Ontario M3J 1P3, Canada. E-mail: Mcondon@Yorku.ca.
} 
the demise of the new economy has been proclaimed by many (Economy and Society 2001), there are still compelling reasons to pay attention to the issue of the regulation of online investing, not least of which is the possibility for retail investors to lose money through the use of technological tools that are not widely understood (Bradley 2004). As detailed in this volume, a number of jurisdictions around the world have addressed aspects of online investing over the last few years. One of the objectives of this paper is to describe Canadian forays into this field of securities regulation, for comparative purposes. In the Ontario context ${ }^{1}$ regulators have attended to the online activities of those who issue securities for trading (issuers), but have focused more intensively on the consequences of online investing for both the broker/investor relationship and for the markets for trading themselves. These regulatory developments will be described in Parts III and IV of the paper. However, these examples of regulatory change also offer the opportunity to consider some timely questions about the nature of regulation in the neo-liberal state. Part II of this paper charts the theoretical ground to be brought to bear on understanding the regulation of online investing in Canada.

\section{THEORETICAL APPROACHES}

The "new economy" of the last several decades held out the promise of using technology to transform the way business was done throughout the economy. As Castells puts it, "the new economy is/will be predicated on a 
surge in productivity growth resulting from the ability to use new information technology in powering a knowledge-based production system" (Castells 2000: 161). The emphasis in the new economy was on innovation, networking, entrepreneurialism, and competition. Critical commentators have noted that these developments have not been without social cost, in the form of more contingent and insecure labor markets, along with increased social inequality and exclusion (ibid.). In the specific context of capital markets, finance was transformed by the liberalization of rules relating to the types of financial transactions that could be conducted within firms, as well as the possibility of more broadly based banking, insurance, and securities transactions. Information technology itself also changed the complexity of, and manner in which, financial transactions could be conducted and the types of financial products that could be sold. As Caroline Bradley notes, information about securities trading opportunities and about the business entities issuing those securities is now available more immediately and arguably in a more user-friendly manner than in the pre-Internet era (Bradley 2004).

If the "new economy" is one metanarrative purporting to describe the reconfiguration of social and economic space in the late twentieth and early twenty-first century, another is the so-called "risk society" thesis. In Ulrich Beck's first account of the risk society (Beck 1992: 19) he proposed that "in advanced modernity the social production of wealth is systematically accompanied by the social production of risks. Accordingly, the problems and conflicts relating to distribution in a society of scarcity overlap with the problems and conflicts that arise from the production, definition, and 
distribution of techno-scientifically produced risks," whether the problem is, for example, BSE or global warming. In this account, technology creates as many problems as the opportunities it enables. For Beck, "the discourse of risk begins where trust in our security and belief in progress ends" (Beck 2000: 213). Thus, the future, more than the past, becomes "the cause of present-day experience and action." Individuals become oriented towards governing themselves so as to avoid potential future risks, such as disease or poverty in old age. As Dean has pointed out, analysts have taken two approaches to the study of risk as it relates to modern society. One approach, exemplified by Beck, is to understand risk as a "feature of the ontological condition of humans" (Dean 1999: 178) within modernity. The other is to address it as a "governmental rationality" (ibid.: 176), that is a discourse and set of practices connected to the "regulation, management and shaping of human conduct" (ibid.: 178). From this vantage point, attention might be paid to what Rose calls "an industry of risk," for whom the characterizing and subsequent assuaging of fears for the future is a profit opportunity (Rose 1999). Furthermore, in this second account, risk as a technique for the governance of populations is congruent with the political project of neo-liberalism, which emphasizes individual responsibility, entrepreneurship, the preeminence of markets, and the withdrawal of the state from the provision of various forms of social insurance and various interventions in the economy (Condon 2002; Ericson \& Haggerty 1997; McCluskey 2002). Making this connection between risk governance and neoliberalism also allows us to see that in actual examples of governance 
through risk, what is at issue is the material distribution of risks in particular ways (Condon 2002; McCluskey 2002).

What is the place of law and regulation in these socio-economic metanarratives? There is now some consensus in the literature on neoliberal practices in various jurisdictions that attempts at deregulation, supposed to result from a neo-liberal agenda, often led in fact to specific forms of reregulation (Braithwaite 2000: 204). For example, despite the fact that online investing can contribute to neo-liberal goals, such as increasing competition among suppliers of trading platforms or allowing individual investors to prepare for retirement more autonomously, the enterprise is being regulated in many jurisdictions. It has been argued that the general form that this re-regulation has taken has been a shift away from models of command and control via a central state apparatus (Black 2001). What is tending to replace this is regulation accomplished using contractual arrangements, codes of conduct, self-regulation, and other more low visibility (and compliance-oriented) mechanisms, that is, so-called decentered regulation. ${ }^{2}$ This development raises a number of important questions, not least of which is, as pursued by Kingsford Smith (2004), the implications of the shift to decentered regulation for traditional notions of accountability to the rule of law. Given the claims of the metanarrative of governance through risk, it is also worth addressing more precisely the connection, if any, between governance through risk and decentered regulation. To what extent have regulatory forms in specific fields empirically begun to shift to a discourse of governance through risk (Condon 2002)? Relatedly, does the phenomenon of decentered regulation 
consequent on the dismantling of traditional state mechanisms for regulating in fact presage a change in the ends as well as the means of regulating? Connected to this is the extent to which the phenomenon of decentered regulation changes the terms of debate about the formation of specific regulatory approaches to dealing with novel issues, such as the growth of online investing. Such debate, in a command and control context, has traditionally investigated the role of private or public interests in explaining the outcomes of state regulatory policy or rulemaking (Condon 1998; Hawkins \& Thomas 1989; Scott 2001). However, a critique of the "governing at a distance" perspective, which argues for deemphasizing the role of the state in accomplishing the governance of populations (Rose 1999), is that it does not pay enough attention to "politics, contestation and implementation" in explaining the formation of specific regulatory initiatives (Callinicos 1999; O’Malley, Weir \& Shearing 1997). For example, is risk governance a feature of the terms in which debate about the formation of regulatory codes for governing online investing is conducted? The examples of policy and rule formation in the area of online investing discussed below can be used to illuminate these questions about decentered regulation and risk governance.

III. INVESTORS, ISSUERS, AND BROKERS

The take-up of online investing opportunities in Canada appears never to have been as vigorous as in the U.S., certainly in those heady days a few 
years ago when Internet trading looked like it might rival the popularity of conventional trading. The Toronto Stock Exchange's (now the TSX) Canadian Shareowners Study for 2000 indicated that Canadian shareholders were "tapping into the Internet at a rapid rate and see the Internet as a crucial source for investment information. For the growing number of people who have tried on-line trading, it has become the overwhelming method of choice" (Market Probe Canada 2000). More specifically, the TSX also reported that 11 percent of shareowners had conducted on-line trades in that year. When the TSX study was updated in 2002, it was reported that although there has been an overall decrease in share ownership in Canada for the first time in twenty years, that "(t)he Internet continues to become a more prevalent means for shareowners to obtain information and conduct transactions, and for many has replaced more conventional channels and become the method of choice." The study went on to predict, however, that "future growth of this medium ... [would] be more gradual than it has been" (Market Probe Canada 2002).

Meanwhile, as Bradley (2004) notes the official regulatory line on technological developments and the information economy is to describe them as "providing investors with empowerment" although investors are also cautioned to "understand the difference between investing and gambling” (Wetston 1999). Ontario Securities Commission (OSC) ViceChair Wetston argued that technology can help reduce the "discrepancy in the information available to large and small investors" and online trading "lowers costs to investors and opens up trading to more investors" (ibid.). On the other hand, "it may fool inexperienced or small investors 
into believing they can "play with the big guys." In particular, Wetston expressed a concern that the "reliance invited by the securities industry when it holds itself out to consumers as primarily an advice provider should be matched by an appropriate level of accountability and responsibility." The investor education section of the OSC's own website includes a number of information sheets on the subject of Internet investing, on the topics of investment information and scams, as well as how-to guides. When addressing retail investors directly, the regulatory approach is clearly to alert investors to the risks involved in using the Internet for obtaining information or trading. ${ }^{3}$ Is the investor-oriented riskbased approach maintained in policy discussions concerning the investor/broker relationship and alternative markets for trading securities? This issue will be taken up below by examining regulatory initiatives in relation to issuers, brokers, and marketplaces.

\section{A. REGULATION OF ISSUERS}

National Policies (NP) 11-201 and 47-201 were effected in December 1999, with the objective of providing guidance to issuers and registrants about the approach that would be taken by the Canadian Securities Administrators (CSA) to the use of the Internet to satisfy various document disclosure and delivery requirements. It is a staple of many regimes of securities regulation that the initial issuance of securities to investors should be accompanied by detailed information about the nature of the securities, the business entity issuing them and its financial status, as well as the "risk factors" involved in 
investing in that enterprise. ${ }^{4}$ National Policy 11-201 supports the electronic delivery of such documents provided certain requirements are satisfied. These revolve around notice of delivery to the recipient, easy access of the recipient to the document, the deliverer being able to show that the document was delivered, and the non-corruption of the document in the delivery process. The CSA indicates that most of these requirements may be satisfied by the deliverer obtaining the prior consent of the intended recipient to electronic delivery. A deliverer may effect electronic delivery without consent, but does so "at the risk of bearing a more difficult evidentiary burden of proving that the first three components of electronic delivery were satisfied" (Notice of National Policy 11-201, $\S 2.1(5))$. Also, reference to a third-party provider of the document will likely "not constitute valid delivery in the absence of consent." The CSA was originally hostile to the use of hyperlinks in relation to electronic delivery of a prospectus (ibid.), but in the final form of the policy it is content to note the risks involved for the issuer in using hyperlinks (including the fact that it becomes liable for the accuracy of hyperlinked material) along with the suggestion that care should be taken by the issuer to ensure that recipients are clear which of the documents being delivered constitute the prospectus. All of this is taken by commentators as evidence that the CSA is reluctant to move away from a restrictive stance of "regulating by analogy" to paper in the context of document delivery (Anand 2001). OSC Vice-Chair Wetston said in an April 2000 speech that, "These policies were deliberately not formulated as a rule in order to give market participants flexibility about how they would use electronic means 
for delivery and distribution" (Wetston 2000). The approach, therefore, is a familiar one in Canadian securities regulation, whereby the state regulator is involved in establishing general guidelines, but room for maneuver is still exercisable by issuers, for example, in how to "take care" in delineating the scope of the prospectus.

National Policy 47-201 deals with two further matters relating to the use of the Internet in connection with trades and distributions in securities. These are: (i) how use of the Internet impacts on jurisdictional questions; and (ii) the approach to be taken to the conduct of "roadshows" over the Internet. The explicit premise of this Policy is that "statutory requirements should not change as a result of the involvement of the Internet" (National Policy 47-201). In relation to the first issue, a "prominent disclaimer" and "reasonable precautions" will suffice to avoid the jurisdiction of the OSC. With respect to the latter, roadshows are acceptable, as long as they are conducted similarly to the procedure for a non-Internet roadshow. This includes the stricture that everyone receiving a transmission must have received a preliminary prospectus, access to a transmission should be controlled, and all viewers should agree not to reproduce the transmission.

Meanwhile, in relation to secondary market disclosure by issuers (i.e., post-initial issue of the securities), in May 2001 the CSA proposed introducing a new National Policy dealing with disclosure standards, which has now been adopted in Ontario. The impetus for this policy was regulatory concern about the issue of selective disclosure of information by issuers to analysts, institutional investors, and other market participants, which was perceived to pose "a serious threat to investor 
confidence in the fairness and integrity of the capital markets" (Request for Comments 2001: 3301). A further specific purpose of the policy is to "assist companies in managing their disclosure obligations and minimize the risk of breaching securities law by highlighting some risky disclosure practices" (Notice of National Policy 51-201: 4460). Again, the objective is to "outline what we consider to be good disclosure practices, not to impose regulatory requirements" (ibid.: 4461). The CSA explicitly compares its policy initiative to the terms of Regulation Fair Dealing (FD) promulgated by the Securities and Exchange Commission (SEC) in the U.S. Canadian securities legislation contains a specific prohibition against tipping, which is where someone in a "special relationship" with the reporting issuer informs anyone of a material fact or material change about the issuer before that material information has been "generally disclosed." The policy indicates that posting information on a company website will not by itself satisfy the "generally disclosed" requirement because Internet access is not yet sufficiently widespread and because information thus posted to a website is not "effectively 'pushed' out to the marketplace" as opposed to investors seeking it for themselves (ibid.). The only entity that commented on this aspect of the proposed policy was a major Canadian law firm, McCarthy Tetrault, which disputed the viability of a distinction drawn in the policy between open conference calls accessible by the Internet (which would satisfy the "generally disclosed" requirement) and postings to an issuer's website (which would not satisfy the requirement) (ibid.: 4480). The CSA defended this distinction by concluding that the former involved active 
dissemination because it would be preceded by a "broadly circulated news release containing particulars of the call and the matters to be discussed," whereas a website posting would not involve such active dissemination. This was despite the law firm's argument that technology could alert interested parties as to when information was posted on an issuer's website (ibid.: 4481).

Despite some level of flexibility accorded to issuers in relation to how they fulfil the requirements of these provisions, it is clear that the state regulators are still engaging in a certain amount of gatekeeping on behalf of investors. The distribution of risk as between issuers and investors implicit in these policies is also affected by the background condition that in Canada investors can still not easily sue issuers for misrepresentations in documents provided to the market beyond the moment of initial issue of the securities (i.e., in the so-called secondary trading market).

\section{B. REGULATION OF BROKERS}

Like the U.S., Canada has experienced the development of discount and online brokerage services, which have the capacity, as Vice-Chair Wetston acknowledged, to transform "the traditional broker-customer relationship as well as ma(k)e investors out of people with no previous experience or real understanding of the stock market" (Wetston 2000). Not surprisingly, the scale of online brokerage activity is much smaller in Canada than in the U.S. Currently, there are some fourteen online brokerage firms in Canada, 
mostly owned by Canadian banks, though Etrade has a Canadian subsidiary. ${ }^{7}$ Deutsche Bank has an ownership interest in an online brokerage called Qtrade. In 2001 the CSA took action against three U.S. online brokers, Datek, Ameritrade, and TD Waterhouse (U.S.), who executed trades on U.S. markets for Canadian residents without being registered to trade in Canada. Each agreed to pay $\operatorname{Cdn} \$ 800,000$, to seek registration and to forthwith comply with the "gatekeeper and know your client obligations" of Canadian securities regulation. ${ }^{8}$ The CSA asserted its jurisdiction in these matters despite the fact that no complaints were made by customers resident in Canada concerning their accounts.

As in other places, the big regulatory development in relation to the impact of technology on broker activities has to do with the pressure to downgrade the obligations to be fulfilled by brokers in dealing with online clients. This issue is clearly connected to questions of the distribution of the risk of making investments as between investors and their advisors. The Canadian path to the removal of suitability requirements for the execution of online trades was influenced, as usual, by developments in the U.S., but also by specific Canadian concerns about the continued viability of the domestic brokerage industry. In 1997 the CSA proposed a new National Instrument, primarily intended to deal with the operation of toll-free lines and electronic trading of securities, particularly mutual funds, by financial institutions (Notice of Proposed National Instrument 33-103). This was originally sparked by regulatory concern about conducting securities activities within retail offices of banks and trust companies. However, the scope of the proposal was not limited to the sale of mutual funds nor to trades by dealers related 
to financial institutions. The proposal purported to permit electronic trading of securities by registered dealers, provided that the system "does not accept transactions outside the suitability range for the client established by the dealer" and referred elsewhere "any order to purchase or sell securities outside the suitability range." This proposal obviously suggests a reluctance to move away from reliance on suitability assessments made by dealers.

In October 1998, a submission was made to the regulators by a group of ten Canadian discount brokerages, including all of the bank-owned ones, requesting that a "process of regulatory change to limit the application of the suitability rule only to brokers who provide advice or recommendations to customers" be initiated (Bank of Montreal Investor Services et al. 1998: 1). Note that the initiative for reform of the regulatory code here was taken by the intermediaries themselves. The arguments made in support of this proposition were formulated in terms of issues such as the need for consistency with U.S. rules, the nature of "regulatory and judicial trends" in the U.S. and Australia in support of such a move, the costs of compliance, and the associated disadvantage to Canadian brokers and stock exchanges in competing with counterparts in the U.S. The submission noted that commissions charged by Canadian discount brokers generally tended to be higher than those charged by their counterparts in the U.S., a source of "numerous inquiries" from customers. It argued that a customer who selects a discount broker has "implicitly made a suitability self-determination and implicitly indicated that he or she does not wish to pay for a suitability determination" (ibid.: 10). 
These pressures, it was argued, were exacerbated by the growth of electronic trading, such that if brokers in Canada failed to "keep pace with their counterparts in the United States, Canadian customers may turn to brokerages in the United States." The group proposed a number of procedural safeguards if their request was met with a favorable response, including advance notification to customers that they would not be receiving advice or recommendations in connection with trades, and that customers who wished to maintain a full-service account would be able to do so, "provided that the accounts be maintained within separate divisions and appropriate safeguards implemented" (ibid.: 12).

The CSA responded to this request in April 2000, when it announced that relief from suitability requirements would be granted on an application basis to dealers who only provided trade execution services for their clients (CSA 2000: 2683). Several conditions were imposed "in order ... to safeguard the interests of investors," which included the setting-up of a separate entity offering execution-only services. Furthermore, individuals were not to be compensated on the basis of the value of the transaction, and the dealer must obtain from the client an "informed acknowledgement" that no advice or recommendation or determination of suitability would be given by the dealer. It is clear that these conditions accorded closely with those suggested by the discount brokers. The approach of requiring specific client acknowledgement was also similar to the manner of regulation chosen in relation to electronic delivery of documents. On announcing this development, the Chair of the CSA said that "this relief from suitability obligations recognizes the changing needs of investors and 
the dealer community" and that the CSA would continue to work with the Investment Dealers Association (IDA) ${ }^{9}$ to explore similar relief for other categories of dealers while still "safeguarding the interests of investors." A number of online brokerages applied for this relief from the suitability requirements, giving representations as to the conditions above enumerated. ${ }^{10}$

The continued discussions that took place between the IDA and the CSA in 2000-1 about the possibility of further extending relief from the suitability requirements to full-service brokers revolved around a number of issues. The IDA used three main arguments to bolster its submission that the CSA should abandon the "functional" approach - that the brokers themselves had suggested - to regulating suitability, in favor of a "trade-bytrade" approach. These were the by-now familiar ones that: (i) other jurisdictions, notably the U.S. and Australia, had adopted the latter model; (ii) Canadian brokerages were being subjected to unfair competition because of the requirement to hive off execution services to a separate division; and (iii) broker obligations to clients would not diminish because of this initiative (IDA 2000-1). Indeed, the IDA asserted that it was their clients" initiative to seek this reform "in order to gain efficient access to the markets and their accounts" (ibid.: 15). With respect to the competition argument, the IDA claimed that the separate divisions requirement created an uneven playing field for them with respect to U.S. brokers. Because they did not have to incur these administrative costs, clients would shift to doing business with U.S. brokers on more favorable terms. Doing business with a U.S. broker would reduce the protection 
available to Canadian clients, who could not access Canadian investorprotection funds and would find it more difficult to seek redress directly from the broker. Meanwhile the requirement created problems for small Canadian firms, less able to withstand the costs of establishing separate divisions, thus having an anti-competitive effect.

With respect to the argument that client protection was not diminished by a move to trade-by-trade determinations of suitability, the IDA's submission noted that the lack of transparency between two halves of the client's trading account could mean greater risk of lack of diversification overall. Clients who wished to have recommendations for some trades and not for others would be denied the opportunity to deal with advisors of long-standing when making execution-only trades. Furthermore, the fiduciary duty owed by brokers to clients would not be diminished as a result of this reform. ${ }^{11}$ A possibility of client confusion about the nature of the services being offered was addressed by the IDA's willingness to require member firms to obtain client acknowledgements of their understanding of the limitations of service being offered, to note whether the trade was "recommended" or "no advice given" on the trade confirmation, and to increase its supervision and review of trading activity to ensure appropriate compliance. This seems to be an example of decentered regulation being proposed to bolster the case for loosening existing restrictions, in a context of shifting understandings of investor exposure to risk. The IDA interpreted existing Canadian case $\operatorname{law}^{12}$ as standing for the proposition that not every client- broker relationship is fiduciary and noted that clients were perfectly free not to follow the 
advice of the broker, foregoing the right to complain in that instance (IDA 2000-1: 11, 15).

In July 2001, the CSA approved the changes to the IDA bylaws and regulations on the topic of suitability (Notice of Commission Approval 2001). The IDA's commentary on its rule changes acknowledged that along with concern in both Canada and the U.S. that there is no rationale for applying the suitability rule to dealers who do not give advice to their clients, there was a further Canadian dimension. This was "the additional concern of the loss of brokerage business and stock exchange activity to the U.S. in light of the rise of electronic trading, the generally lower broker commissions offered by the U.S. discount brokers and the less onerous suitability obligations imposed on American dealers" (IDA 2001: 2923). Furthermore, the IDA acknowledged that "compliance costs over time will be reduced without the requirement to conduct a suitability review for each and every transaction" (ibid.: 2924). It was also asserted that their new policies would be in the public interest by facilitating "an efficient, fair and competitive secondary market" (ibid.: 2926). This would be accomplished "by ensuring that investors receive the services they want and Member firms are able to offer services similar to those available in the U.S." (ibid.). They should also "decrease delays that currently exist in the industry through increased transactional efficiency" (ibid.). The IDA concluded that "Investors have expressed a desire to make their own investment decisions in respect of their assets as evidenced by the growth of discount brokers in the industry today. Thus, investors are not looking for a paternalistic refusal by the dealer to process an order" (ibid.: 2927). 
A number of conditions for obtaining relief from suitability on a tradeby-trade basis were imposed. These were as follows:

1. Where a firm wanted the flexibility to provide recommendations or not, new client application forms would have to request suitability information (age, investment objectives, risk tolerance, investment knowledge, net worth, and income) so that it could be reviewed for recommended transactions.

2. Approval for suitability relief would have to be obtained from the IDA in accordance with its Policy No. 9. This policy, requiring disclosure of the fact that a firm will not be responsible for making suitability determinations when accepting an order that was not recommended is intended to ensure that "appropriate safeguards are implemented in order that clients will understand the differences in the types of transactions that they wish to execute, the possible risks associated with such transactions, and the client's increased responsibilities when an order-execution only transaction is requested." This would largely be accomplished by obtaining signed acknowledgements from clients as to their responsibility for their own investment decisions when no recommendation is provided. The policy also requires the disclosure to the client to include a brief description of what does and does not constitute a recommendation. ${ }^{13}$

3. The policy also introduced supervisory systems to ensure that clients are not provided with recommendations where a suitability determination is not undertaken, including accurate marking of orders as recommended or non-recommended, monthly reviews of accounts, and trade confirmations 
to indicate if transaction was recommended or non-recommended.

The end result of all this, then, is that full-service brokers in Canada are able to offer execution-only services to clients, who may opt in and out of an advising relationship with the broker as they see fit. While this enhancement of choice for the retail investor may be interpreted as an escape from paternalism, it also contributes to a shift in the ground rules for the operation of an industry that had been relied upon to perform classic intermediation and gatekeeping functions. It places more responsibility on the industry itself to ensure that the relevant safeguards to do with client understanding of service levels are working appropriately. In this sense, it is possible to see this example of policy formation as exhibiting decentered elements. Ironically, the de-emphasis on the intermediation and fiduciary functions to be performed by the brokerage industry may over time undermine the core arguments used to justify the selfregulation of the industry. Significantly however, this example of a policy formation process proceeded along familiar lines, with industry groups concerned, at least in part, for their competitive position playing a pivotal role in the way legal governance in this area was formulated.

In terms of our inquiry about risk as an element of the governance of (investor) populations, we have noted that the imposition of suitability requirements has always been about the management of the risk tolerance of investors. With the introduction of execution-only services provided by brokers in the online context, however, more of an onus is being placed on the investor to be aware of, and to contract for, the level of suitability 
assessment and advice she/he requires. Responsibility for overseeing the procedures for managing that aspect of the broker/investor relationship is primarily placed at the local-firm level. With these innovations, it seems likely that basic assumptions about the level of independent decision-making risk being assumed by retail investors in entering into the trading of securities may change. This development, coupled with the increasing recourse of individuals to equity markets to prepare for personal retirement well-being, as well as the evidence from behavioral finance theorists about the deficiencies of market decision-making by investors (Barber \& Odean 2001), suggests that a high price might ultimately be paid by investors in Canada for the protection of its brokerage industry from international competition.

\section{REGULATING MARKETPLACES}

An issue that goes to the core of the growth of online investing is that of the proliferation of markets on which securities can be traded online. The development of trading technology makes it possible for more providers to enter the market for marketplaces. In the Canadian context, again following suit from the U.S., regulators recently considered the issue of what to do about so-called alternative trading systems (ATS), which provide automated matching systems bringing together orders from multiple buyers and sellers. In accordance with new economy imperatives, the policy debate was conducted using discourses of competition, efficiency, anonymity, choice, and cheaper information costs. However, 
along with these ideas came the peculiarly Canadian concern with market fragmentation and consequent illiquidity. What is different from the suitability example considered above is the somewhat broader cast of characters in relation to ATSs, which include established trading markets, and both institutional and retail investors. Canadian imperatives for the regulation of ATSs implicated at least two distinctive features of domestic capital markets, the size of the Canadian market for capital relative to that in the U.S., and the highly concentrated nature of the domestic financial services sector. In relation to the first issue, regulators articulated a fear that the advent of choices about marketplaces on which to trade securities would result in the development of a "capital market controlled and directed by other countries, in which only premium Canadian companies and major-league Canadian investors will be able to participate" (Brown 1999). Thus the discourse of "the survival of an independent capital market in Canada" and a fear of being swamped by new players with agendas not consistent with Canadian national interests framed the policy debate about how to regulate ATSs. With specific reference to the growth of ATSs in the U.S., Brown noted that "Alternative trading systems are about choice. If money managers or investors don't have that choice, they will take their business elsewhere.”

Regulators presented the survival of Canadian capital markets as necessary to meet the needs of Canadian issuers and investors. However, another relevant aspect of the context here is the economics of the domestic financial services sector. In November 2000, William Hess, then the President and CEO of the Canadian Venture Exchange (CDNX) 
noted that the trading activities of all five of the bank-owned brokers on the Toronto Stock Exchange account for 53 percent of the TSX's trading volume and ten brokerage firms represent 80 percent of the TSX's volume. The fear articulated by the established exchanges then is as much about losing market share to competing ATSs set up by one or more large Canadian banks or investment dealers as it is about competitors from the U.S. (such as Instinet or Archipelago) entering the Canadian market for marketplaces. Added to this is what Brown describes as a measurable growth in the "upstairs" market, that is, the practice of crossing large blocks of shares for institutional customers off the exchange itself. Therefore, one hypothesis about stock exchange responses to the introduction of the new rules for the operation of ATSs is that they are concerned to protect their own ongoing economic interests. In preparation for the advent of competing markets, the provincial exchanges in Canada underwent some consolidation in the late 1990s, so that there are now three of them, the TSX for senior issuers, the TSX Venture Exchange for junior issuers,${ }^{14}$ and the Montreal Exchange, which operates the only derivatives market.

In August 2001, the CSA published its final instruments dealing with the regulation of marketplaces and trading (NIs 21-101 and 23-101). The articulated goals of the rule are to "provide investor choice, improve price discovery, and decrease execution costs." The primary elements of these complicated rules will be described below. 


\section{A. DEFINITIONS}

The new framework to permit "the competitive operation of traditional exchanges and other marketplaces, while ensuring fairness and transparency" begins with the definition of a marketplace. This means: (a) an exchange; (b) a quotation and trade reporting system (QTRS); ${ }^{15}$ or (c) a person or company that (i) constitutes, maintains or provides a market or facility for bringing together buyers and sellers of securities, (ii) brings together orders for securities of multiple buyers and sellers, and (iii) uses established, non-discretionary methods under which orders interact and buyers and sellers agree to trade terms. ${ }^{16}$ The key feature of a marketplace then is the capacity to execute trades from multiple buyers and sellers.

Meanwhile, an ATS means a marketplace that is not an exchange or QTRS and does not: (i) require issuers to enter into agreements to have their securities traded on the marketplace; (ii) provide a guarantee of a two-sided market on a continuous or reasonably continuous basis; (iii) set requirements governing the conduct of subscribers, except with respect to trading and creditworthiness (NI 21-101 CP \$3.1(3)); and (iv) does not discipline subscribers other than by exclusion from participation in the marketplace.

The characteristics of ATSs are established so as to draw a clear distinction between them and organized exchanges with respect to regulation of issuers, disciplining of members/subscribers, and a guarantee of a market. The absence of a guarantee of a two-sided market, which is also relevant in connection with the regulation of payments for order 
flow, imports some uncertainty about liquidity into the very definition of an ATS, despite the fact that increased liquidity is one of the policy goals of allowing ATSs to operate. Thus the regulation introduces a level of fragmentation and complexity into the very idea of a market, which is, as we have seen, one of the core mechanisms of neo-liberal policy. It also facilitates a range of options for the manner in which investors may be governed.

In order to carry on business, an ATS must: (i) be registered as a dealer; (ii) be a member of a self-regulatory organization (SRO); ${ }^{17}$ and (iii) comply with the provisions of NI $21-101 .^{18}$ Those who may trade are called "marketplace participants." For an ATS, such a "participant" is called a "subscriber," that is, someone who has entered into a contractual agreement with the ATS to access it "for the purpose of effecting trades or submitting, disseminating or displaying orders on the ATS." There is no requirement that a subscriber be registered as a dealer, so both retail and institutional investors could be subscribers to an ATS. ${ }^{19}$ Indeed, one of the cited advantages of ATSs to institutional investors is that the possibility of being able to make trades directly, as opposed to through a dealer on the exchange, allows their trading to be more anonymous and therefore, if it involves large blocks, to have less of an adverse impact on pricing. Exchanges and QTRSs are not allowed to prohibit or limit members or users from effecting transactions on any marketplace (NI 21101: §5.2), nor are ATSs (ibid.: §6.12). ATSs have to disclose their trading fees to an information processor, including whether different fees are charged to subscribers and non-subscribers. They are not 
allowed to charge fees to non-subscribers such that they create barriers to access.

\section{B. WHAT CAN BE TRADED?}

A significant feature of the rules relating to ATSs in Canada is that, at present, the types of securities that can be traded on them are restricted to exchange-traded securities, corporate debt securities, government debt securities, and foreign exchange-traded securities. An earlier version of the rule had required only that an ATS security be a security issued by a reporting issuer in Canada, government debt, or a security listed or quoted on certain foreign markets. All three of the TSX, the CDNX (as it then was), and the IDA responded to this proposal with dire warnings about the implications of ATSs trading unlisted securities. The CDNX proposed that by not requiring issuers to be listed on an exchange or registered with a securities regulator "the potential for reputational damage to the Canadian capital markets is significant" (Hess 2000: 2). It asserted that the ATS proposal as it existed in 1999 "allows those companies that want to avoid scrutiny to go public outside of the closed system ... and make a Canadian ATS their principal or sole marketplace, while avoiding the reporting issuer obligations in securities legislation." The TSX was equally concerned about the possibility of ATSs "becoming a new home for trading in unlisted penny stocks" (Stymiest 2000: 14). In response to these views, the CSA amended the rule so that ATSs would only be permitted to trade the types of securities described above. This ensures that, at least in 
relation to equity securities, those traded on an ATS are also traded on at least one more senior marketplace. Another way of putting this obviously, is to say that TSX and one or more ATS compete for orders related to securities listed on the TSX.

However, a marketplace trading unlisted equity securities can apply for approval from the OSC. The first entity that sought to be regulated under the new rules was the Canadian Trading and Quotation System (CNQ). Regulatory approval for its operation as a QTRS was granted in March 2003. This entity is "owned by a group of private investors" and trades non-exchange listed equity securities by approved IDA members. More generally, the rules allow an ATS that wants to trade over-the-counter equity securities to apply to the CSA. It may allow an ATS to trade these securities if it is not contrary to the public interest to do so. It should be noted, in connection with the issue of decentered regulation, that the government regulators retained discretionary decision-making power in relation to who could operate an online marketplace, or the terms on which it might operate. To determine the public interest in this respect, the CSA "look at a number of factors including whether there are appropriate arrangements for issuer regulation" (Notice of National Instruments, Companion Policies and Forms: 91). Thus, adequate arrangements for regulation are central to the determination to allow a marketplace to operate. 


\section{GROUND RULES FOR MARKET OPERATION}

All marketplaces are subject to requirements about information consolidation, market integration requirements, reporting/record-keeping requirements, and systems-capacity requirements. The information consolidation and market integration rules are an attempt to "preserve the benefits of a centralized market" (Kerbel and Wade 1999: 2), in the sense that information will be available to subscribers as to the prices at which securities are trading on other markets. Originally, the information transparency provisions would have required all marketplaces that display orders of exchange-traded securities or foreign exchange-traded securities to provide information on these orders to a data consolidator by December 2003 (NI 21-101: §7). ${ }^{20}$ In the meantime, marketplaces were required to provide details of all trades to an information vendor, which could be any one of a number of entities, such as the TSX or Reuters. This order and trade information must be provided to the information vendor in real-time or as close to real-time as possible. Before the rule was implemented, these transparency requirements were criticized by a number of industry participants on the ground of their cost to the industry and investors. Since then, the implementation of the requirement to provide information to a data consolidator has been delayed pending further investigation of the need for, and the appropriate extent of, information transparency requirements by an industry committee. In the meantime, an information vendor is expected to meet requirements imposed by a regulation services provider with respect to "the process, the business content of the reporting and regulatory data feeds, including the core data 
elements, the message catalogue and the service level standards" (Amendments to NI 21-101 CP: §1.1 (8)).

Meanwhile, the market integration rules, which are designed to allow access to the orders displayed by the information processor, were intended to be introduced in two phases. In the first phase, to last until 1 January 2004, marketplaces could not execute trades of securities unless they had an "electronic connection" to the "principal market" for the security. The principal market would be identified by the information processor, "following the enactment of the Instrument and each year" (NI 21-101 CP: §11.1(3)) as "the marketplace that had the largest trading volume for that security in that calendar year." The connection to the principal market allows subscribers to an ATS to access orders in that market, if not in all marketplaces trading that security. The implication of this, of course, is that unregistered ATS subscribers, i.e., retail or institutional investors, could trade securities listed on the TSX without the intervention of a broker. This is particularly likely to be the case in the first period of operation of this system, since the principal market, at least initially, is the TSX. The other implication though is that during this transition phase, subscribers could see better offers from marketplaces other than the principal market, but were not able to access them directly. This suggests that fulfilling the goal of equal access to the best price available will take some time to be accomplished..$^{21}$ 


\section{REGULATION OF ATSs}

A significant feature of the rule is that, as well as providing for the development of new marketplaces giving investors additional choices, marketplaces themselves also have choice about how they will be regulated. The options they may choose among are to be regulated as: (i) a member of an exchange; (ii) as an exchange; or (iii) as an ATS. An ATS will not be expected to discipline its subscribers or establish listing requirements for issuers. The approach of allowing choices among forms and intensity of regulation suggests that, as neo-liberal thinking would have it, regulation itself is being increasingly fragmented along with the markets, such that the intensity of regulation will vary among entities performing similar trading functions.

National Instrument 23-101 sets out a number of minimum requirements as to how trading on all marketplaces is to be conducted. The substance of this instrument deals with prohibitions on manipulation and fraud in trading practices, ${ }^{22}$ the application of trading halts, ${ }^{23}$ best execution requirements, and establishment of trading hours. ATSs are exempt from the best execution requirements. More generally, marketplaces are exempt from the application of these rules if they comply with rules and policies established by a recognized exchange, a recognized QTRS, or a "regulation services provider," whose rules will be reviewed and approved by the regulators. Other substantive provisions in an earlier version of this rule dealing with issues such as short selling, insider trading of securities of foreign nonreporting issuers, front running, an order exposure rule, and principal trading have been omitted altogether 
from the final version of the trading rules, and have been delegated down to regulation services providers to handle. This seems to suggest a level of decentering in relation to regulating the ongoing market activities of ATSs. The CSA will "review its proposed rules to determine if these provisions are included and whether the specific provisions are appropriate in the context of that market, marketplace or security." The logic here is that "identical provisions are not necessarily appropriate for each type of market, marketplace or each type of security." This delegation down of the regulation-setting function may allow for the possibility of different trading rules for different marketplaces (and consequent possible confusion for investors), and also might require marketplaces to change their regulation depending on the type of security that trades there. ${ }^{24}$ Exchanges and QTRSs may either govern the conduct of their members/users directly, or by agreement with a regulation services provider. The Companion Policy to NI 23-101 indicates that the regulators expect marketplace participants to transact business "openly and fairly and in accordance with just and equitable principles of trade (NI 23-101 CP: §1.2)." Meanwhile, as we have seen, ATSs cannot carry on business unless they are registered as dealers, are members of an SRO, and comply with NIs 21-101 and 23-101. ATSs have to keep subscribers' trading information confidential, including the identity of subscribers and their orders unless the subscriber otherwise consents, or the information is required by law to be released (such as, presumably, insider reporting rules). They are required to provide risk disclosure to subscribers who are not dealers, to the effect that they do not ensure best execution for 
subscribers. Subscribers are required to acknowledge that they have received this disclosure before their first order is traded (NI 21-101: §6.11). Significantly, ATSs are required to enter into a contract with a "regulation services provider" that will set requirements for ATS trading, monitor the trading activities of the ATS and its subscribers, and enforce its own rules (NI 23-101: §8.2). The regulatory body for an ATS has to be recognized by the OSC before any ATS can start trading. The recordkeeping requirements for marketplaces are found in Part 11 of NI 21-101. ATSs also have to enter into agreements with their subscribers that the latter will comply with the requirements of the regulation services provider. This arrangement also appears to be consistent with neo-liberal modes of governing through decentralized contractual agreements rather than the content of regulation being centrally imposed by the government regulator. Indeed the very language of "regulation services provider," used for the first time in Canadian securities regulation, turns on its head the notion of regulation as a set of authoritative pronouncements from a centralized power and implies that "regulation services" are themselves another commodity to be bought and sold in the market. Again there is evidence of an increasing fragmentation of regulatory systems as well as of markets. However, the state regulators have retained the power to oversee the activities of regulation services providers, by way of, for example, requiring periodic reporting of their regulatory activities, approval of "significant changes" in the way regulation services are provided, and reporting of market misconduct if investors may suffer "serious damage" or there are grounds to believe fraud may be involved, as well as notification 
of "material systems failures and changes" ${ }^{25}$ (In the Matter of Market Regulation Services 2002: 925).

A specific regulatory issue that caused some controversy among commentators on the CSA's draft rules in relation to ATSs was that of payment for order flow. The TSX wanted the CSA to prohibit this in its trading rules, on the basis that if ATSs were allowed to pay for order flow, this would create "a clear conflict of interest for firms routing client orders ... based on financial benefits to the brokerage firm rather than ... best execution." On the other hand, the Investment Dealers Association, some of whose members might potentially establish ATSs themselves, "strongly oppose[d] a ban on payment for order flow or preferencing." It argued that this would be anti-competitive, and the problem of conflict of interest could be adequately handled through a best-execution rule combined with monitoring by the relevant SRO. Ultimately the CSA took refuge in the idea that once "one party guarantees execution for a price, they have provided a guarantee of liquidity. Consequently that party must be recognized as an exchange." As we have seen there is no best execution requirement for ATSs, only intermediaries. Similarly, an earlier version of the ATS rule would have prohibited owners of an ATS or their affiliates from trading securities on the ATS for their own account. This was apparently designed to prevent dealers with large volumes of trading from withdrawing from exchanges and setting up their own ATSs for their customers. This prohibition has disappeared from the final version of the rule. The implications here, obviously, are that an ATS could potentially trade for itself as a buyer or seller, in the 
absence of any best execution requirement.

E. ENTER MARKET REGULATION SERVICES INC.

As might be predicted by a scholar of decentering, the model of instituting a "regulation services provider" to regulate trading in an ATS was considered preferable to direct regulation by the CSA or to regulation of an ATS by the TSX, likely to be an ATS competitor and therefore not acceptable to them as a regulator. However the TSX moved quickly to, as it were, capture the market for regulation by establishing a company called Market Regulation Services Inc. (RS), which it jointly owns with the IDA. The TSX and TSX Venture have retained RS as their regulation services provider with the approval of securities regulators, and RS has been approved as an SRO in five provinces, including Ontario. The hope of RS's owners is that it will be retained to provide similar services to other marketplaces. As the rules require that regulation services providers must be SROs, it is likely that this may occur. According to Tom Atkinson, the CEO of RS (Blackwell \& Dixon 2001: B2), "a few [ATSs]" approached RS about providing regulatory services soon after its inception. These include CNQ, which began operating in summer 2003, and which has retained RS to provide it with market surveillance and regulatory oversight services.

The recognition order granted to $\mathrm{RS}$ by the government regulator in January 2002 includes terms and conditions in relation to corporate governance, fees chargeable, access of ATSs to RS's services, financial 
viability, systems capacity, as well as the rule-making and discipline exercisable by RS. Thus it is arguable that a relatively detailed template of internal organization and ongoing operation has been provided to RS by the regulators. For example, $\mathrm{RS}$ is required to have a board where at least 50 percent of its directors are "independent," as defined in the order, and where "at all times," at least one of its directors represents ATSs. It is not allowed to "unreasonably prohibit or limit access to its regulation services." In relation to financial viability, RS is required to operate on a not-for-profit basis, and to have a "risk management policy that will allow it to identify issues that may prevent it from allocating sufficient financial and other resources to carry out its regulation functions in a manner that is consistent with the public interest." Its fee structure is composed of a relatively modest fixed annual fee chargeable to "participating organizations" of TSX or TSX Venture or ATS subscribers, and a variable fee per shares traded. New marketplaces are also charged a one-time fee for providing them with a connection to RS's systems. Its rules, which must be filed with regulators, are required to be "not contrary" to the public interest and to ensure compliance with securities legislation, prevent fraud, and promote just and equitable principles of trade.

In an early news release, Atkinson described RS as Canada's first “independent and national market regulator." RS's mission is described as being to "develop, administer, surveil, and enforce market integrity rules applicable to trading in Canadian securities markets in a neutral, cost effective, service oriented and responsive manner that does not preference one type of market over another." The TSX and TSX Venture have 
promulgated a set of Universal Market Integrity Rules (UMIRs), which are being used by RS to regulate the markets for which it is the regulation services provider. These rules apply to the operation of marketplaces (such as order entry, transaction record, and trading halt rules), participants ${ }^{26}$ (including conduct of business in accordance with just and equitable principles of trade, prohibition against short selling, and front running), and access persons. In August 2002, RS published a set of sanction guidelines for its disciplinary proceedings, indicating the range of monetary and other sanctions that would be applied for breach of UMIRs provisions.

In a recent interview, Atkinson repeated a view that he expressed when RS was first established, to the effect that "Enforcement is probably the least effective form of enhancing market integrity" (Tedesco 2003: FP6). The same source reports that "during its inaugural year, RS has issued 300,000 alerts to traders for possible rule violations; it has vetted over 40,000 corporate press releases and on average, monitored 110,000 trades a day." It has also made a request to the CSA for "sweeping powers, among them the ability to subpoena witnesses, to compel individuals and companies to co-operate during investigations and to appear before a disciplinary panel; and enable them to collect on the financial penalties resulting from disciplinary action."

It is worth noting that the model adopted here, where a provider contracts to provide regulation services to a market, results in the regulator being functionally detached from the market. This detachment has been something for which state regulators were regularly criticized. 
The model adopted here is clearly something of a "third way," in that it is neither state nor self-regulation as these have been generally understood. Is it decentered? The commodification of regulatory power implied in this model does suggest a destabilizing of the state command-and-control model. However, the fact that in practice, the TSX and IDA are currently the owners of the regulation services provider ${ }^{27}$ suggests that the model in Ontario is in fact closer to self-regulation, with theoretical competition among regulators for the business of regulating markets providing a "new economy" spin. These established interests appear to have maintained their influence over a regulatory process designed to promote broader competition, new players, and greater choice for online investors.

\section{CONCLUSION}

The evidence presented here reaffirms the point that if the growth of online investing is associated with neo-liberal competition and entrepreneurship among market providers and intermediaries, competition is also being managed by regulatory processes (Braithwaite 2000). In terms of our empirical inquiry into whether the approach to regulating online investing in Canada exhibits a commitment to decentering the state, the results can be described as somewhat mixed. On the one hand, delegating responsibility to individual brokerage firms for monitoring the operation of suitability disclosure in relation to online transactions and allowing issuers flexibility about the presentation of Internet-based prospectus material 
suggests a minimal role for state regulation. Adopting a market model of regulatory structure in relation to ATSs - by way of the innovation of the "regulation services provider" - seems to be the clearest example of decentering the state. On the other hand, this market model is accompanied by a relatively robust system of state oversight. Similarly, we have noted that a generally conservative approach has been taken in Canada to the use of the Internet for document delivery and disclosure. In this sense, Braithwaites' observation that the role of government in the "new regulatory state" is to regulate the standards of private-sector service providers is demonstrably reinforced (ibid.: 226). But while it is clear that the form and nature of the regulatory strategies being employed in the online investing sphere are becoming more variable and multi-institutional, the evidence does not appear to support the more radical proposition that "authority itself" is being devolved (ibid.: 228). In particular, the phenomenon of using investing technology itself to do the regulating, which might be considered the pinnacle of an embedded approach to the regulation of online investing, is not yet a pervasive feature (Black 2001: 138).

The other prong of our inquiry - empirical evidence of a shift to risk governance as a modality of regulating - has again produced ambiguous results, in the sense that "risk knowledges" appear to be selectively mobilized (Valverde, Levi \& Moore 2003). While the capacity for online brokers to offer execution-only services to investors might well be construed as a redistribution of the risk of making investment decisions from intermediaries to customers, when the context shifts to 
the delivery of issuer documents, regulators were reluctant to engage in a similar redistribution. The marketizing of the regulatory apparatus for ATSs suggests that individual and institutional investors might have to factor in the credibility of the regulatory structure in making decisions about where to trade. Investors will increasingly be contracting for regulatory effectiveness as part of making investment choices. The absence of a best-execution requirement for ATSs may increase the level of risk incurred by investors choosing an ATS as their trading platform. Yet discourses of risk and risk management appear to be targeted predominantly at individual investors rather than more established industry players. The approach to setting ground rules for the operation of ATSs could be interpreted in terms of regulators managing the risks of their arrival by way of rules about what can be traded, transparency obligations, and, significantly, requirements for regulatory services. Yet, it is apparent that the emerging regulation of ATSs in Canada is also oriented around traditional legal discourses of avoiding conflicts of interest in the operation of new markets or even public choice discourses about accommodating the ongoing economic interests of established institutional entities. What the case of regulating online investing in the Canadian context does seem to make clear, however, is the need to pay careful attention to the politics of decentering and risk governance. The absence of individual investor voices in debates about how to regulate in this field is notable. The decentering impulse driving both the online suitability assessment issue and the regulation of ATSs was clearly connected to the economic interests of repeat players in the field, such as investment banks 
with online brokerage subsidiaries, as well as the TSX and IDA, the owners of RS. In relation to risk governance, this case study provides scope for an argument that while individual investors might be increasingly governed through this modality, with online trading technology being interpreted as a source of risk to them, institutional entities like brokerage houses or new marketplaces are given more autonomy about whether or not, or how, to engage with discourses of risk management. In other words, it remains important to explore the political conditions under which risk discourses are mobilized (McCluskey 2002; Valverde Levi \& Moore 2003). Given these realities, there is room for skepticism that the online investing context will produce a significantly greater degree of investment market democracy in Canada.

mary condon is an associate professor at Osgoode Hall Law School, York University, Toronto. Her current research interests, apart from online investing, include pension policy and regulation of pension funds and mutual funds, socially responsible investment, gender and economic citizenship.

\section{NOTES}

1. Securities regulation in Canada is provincial, so that provincial regulators make regulation and policy affecting that province only. However, an umbrella organization called the Canadian Securities Administrators (CSA) has over the last few years attempted to promote a harmonized approach to Canadian securities regulation by promulgating "national instruments" or "national 
policies" that may be adopted as rule or policy in individual provinces.

2. Kingsford Smith provides an insightful account of the development of this perspective in her paper in this volume. See also Black (2001).

3. Thus, these information sheets contain comments such as "If you are considering an online investing opportunity, keep in mind that the Internet is unregulated ... just because information is available doesn't necessarily mean it's true" (Beware of Internet Investing: Scams); "While computers can speed up the trading process, don't make the mistake of thinking trades happen instantly" and "While trading on margin may magnify the size of your returns, it is risky because it also magnifies the size of any losses" (Thinking of Investing Online?); "Investors who venture into the online world ... should keep in mind that the power of the Internet is also being exploited by investment con artists and fastbuck operators who want nothing more than to separate you from your hard earned money" (Investing and the Internet - Be Alert to Signs of Fraud).

4. In Canada, the document that provides this information to investors is known as a prospectus.

5. Thus "where delivery is intended by posting a document, such as on the Internet, the notice requirement could be satisfied by providing notice to each intended recipient at the time that a document is available or by obtaining the recipient's prior informed consent to this form of delivery" (Requests for Comments 1999: 7786). As to evidence of delivery, the CSA view is that "the best form of evidence of electronic delivery is proof that a document was sent electronically in accordance with the terms of the prior consent of the recipient" (ibid.: 7788).

6. This is the term used to describe the permissible limits of information about the business entity and the security being offered that can be provided to potential investors by investment bankers in advance of the prospectus being approved by regulators. 
7. Charles Schwab Canada was purchased in 2002 by Bank of Nova Scotia.

8. These are now to be found in Rules 31-505 (Conditions of Registration) and 31502 (Proficiency Requirements).

9. The IDA is the main self-regulatory organization for brokers and dealers in Canada.

10. They undertook to continue to adhere to the suitability requirements for those clients from whom an acknowledgement was not obtained for a six-month period following the date of the application decision. However, some were required to make applications to extend this period for a further six months in order to have additional time to obtain the client acknowledgments.

11. A concern expressed by the CSA that there could be a conflict of interest resulting from referral payments made by order-execution only brokers to their fellow broker-advisors was dismissed by the IDA as "unrealistic" and "contrary to the successful operation of an individual broker's full-service business."

12. Notably Varcoe v Sterling 1992.

13. Here an IDA notice to members indicates that making "investment information" (e.g. news, research, opinions, asset allocation models, portfolio tracking information, public disclosure documents, etc.) available to one or more customers would not constitute a recommendation provided that a proposal is not "individually tailored for the particular customer or class of customers." Related to this, if a customer "sets out the parameters of the types of investment information that he or she wishes to receive," providing that information would not be considered a recommendation. On the other hand, systems for "data mining" customers' habits and investment preferences based on past investment decisions and using this to target investment-related information to those customers might constitute a recommendation. A recommendation might also be involved where the broker held herself out as 
taking into account the customer's objectives and financial situation in relation to a transaction.

14. This used to be the Canadian Venture Exchange (CDNX) until it was acquired by the TSX in 2001 .

15. This is a person or company other than an exchange or registered dealer, that operates facilities permitting the dissemination of price quotations for the purchase and sale of securities and reports of completed transactions in securities for the exclusive use of registered dealers.

16. Such non-discretionary methods include rules imposing execution priorities, e.g., time and price priority rules. A person or company brings together orders for securities if it displays trading interests entered on the system or receives orders centrally for processing and execution (NI 21-101 CP: §2.1(3)).

17. The requirement of membership in an SRO is intended to ensure that investors are protected by the Canadian Investor Protection Fund as well as SRO regulations about capital requirements for members. The regulation acknowledged that at this time the only SRO available for an ATS to join was the IDA, the SRO for brokers and dealers. Unlike the TSX, the IDA does not operate a market itself. TSX member regulation functions were recently transferred to the IDA, in connection with the demutualization of the Exchange.

18. Section 6.7 of the instrument requires an ATS to notify the regulators if its trading volumes or dollar values of any "type of security" are equal to or greater than 20 percent of all value or volume in that type of security on all marketplaces in Canada. Once those thresholds of "market dominance" are reached, the regulators will consider whether the ATS is more appropriately considered to be an exchange, even if it is not performing the functions that distinguish an exchange from an ATS, such as listing issuers or disciplining members. 
19. The structure of the registration requirements for securities trading is such that investors generally are only exempt from them if they "trade through an agent who is a registered dealer." This is accomplished by the ATS being designated as a dealer for some purposes.

20. Marketplaces have to provide at least information on the type, the issuer, the class, the symbol and the series of the security, the five best bid prices and five best ask prices for each security displayed, and the total disclosed volume at each of those prices.

21. Beyond January 2004, marketplaces were to be required to have agreements with a market integrator and to comply with its requirements, or if none exists, they were to "establish and maintain electronic connection to all other marketplaces trading the same securities." The companion policy to the rule indicates that "Phase 2 integration will establish more complete market integration and order routing between all marketplaces in order to ensure that there will be price protection for all orders between all competing marketplaces" (NI 21-101 CP: \$11.1(5)). So ATSs would at this point have to take responsibility for facilitating the access of their subscribers to all marketplaces trading the same securities. It should be noted of course that there is no requirement to automatically route orders to the best priced market, since ATSs have no duty of best execution (NI 23-101, Part 4). The CSA would have considered an ATS not to be in compliance with this access requirement if it responded to orders from nonparticipants more slowly than from its own participants, or it used different technology that did not provide equivalent service to execute non-participant orders, or it charged fees which had the effect of creating a barrier to access for non-marketplace participants. Again there was criticism of this requirement by industry participants on the ground of the cost and complexity involved in achieving connectivity. The CSA has now, as of January 2004, backed away from the more robust requirement for market integration, by deleting the concept of 
"market integrator" in the rules. Instead the focus will be on "ensuring compliance with best execution requirements for dealers and fair access requirements for marketplaces" (Notice of Proposed Amendments to NI 21101: 4379).

22. These include: wash trading or effecting transactions that have the effect of artificially raising/lowering or maintaining prices. See NI 23-101 CP: §3.1.

23. Here the idea is that if one marketplace halts trading in a particular security, no other marketplace can trade it either.

24. For example, if a marketplace began trading foreign non-reporting issuer securities.

25. For an example of the terms of an "oversight program," see the Memorandum of Understanding regarding oversight of Market Regulation Services Inc. between the Alberta, British Columbia, Quebec, Manitoba, and Ontario Securities Commissions.

26. These are members of an exchange or dealers operating on an ATS, but not those who are merely "subscribers" to an ATS.

27. An example of the complex relationship between RS and at least one of its owners, the TSX, is an issue that caused some controversy among those interested parties that commented on the proposed structure and operation of RS before its approval by the regulators. This was the fact that the TSX charges RS for the use of its surveillance systems, which may then be used by RS to surveil markets other than the TSX. RS agreed to investigate the cost of obtaining comparable services from a third party. 


\section{REFERENCES}

Anand, Anita Indira (2001) "Securities Law in the Internet Age: Is 'Regulating by Analogy' the Right Approach?," Queens Law Journal 27: 129-60.

Bank of Montreal Investor Services Ltd., CIBC Investor Services Inc., CT Securities Inc., Green Line Investor Services, Hongkong Bank Discount Trading Inc., Priority Brokerage Inc., Royal Bank Action Direct Inc., Scotia Discount Brokerage Inc., Sun Life Securities Inc., VERSUS Brokerage Services Inc. (1998) "Re: Suitability Rules.” Submission to Canadian Securities Regulators, 1 October.

Barber, Brad M., and Terrance Odean (2001) "Boys Will Be Boys: Gender, Overconfidence and Common Stock Investment," Quarterly Journal of Economics 116: $261-92$.

Beck, Ulrich (1992) Risk Society: Towards a New Modernity. London: Sage Publications.

Beck, Ulrich (2000) "Risk Society Revisited: Theory, Politics and Research Programmes." In The Risk Society and Beyond, edited by B. Adam, U. Beck \& J. Van Loon. London: Sage Publications.

Black, Julia (2001) "Decentring Regulation: Understanding the Role of Regulation and Self-Regulation in a 'Post-Regulatory' World," Current Legal Problems 54: $103-46$.

Blackwell, Richard, and Guy Dixon (2001) "Brokerage Profits tumble," Globe and Mail December 8: B2.

Bradley, Caroline (2004) “Online Financial Information: Law and Technological Change," Law \& Policy 26: 375-409.

Braithwaite, John (2000) "The New Regulatory State and the Transformation of Criminology," British Journal of Criminology 40: 222-38.

Brown, David A. (1999) "Present At the Creation: New Century, New Trading Systems." 
Address to the Canadian Club, 12 April, OSC Bulletin. 22: 2252.

Callinicos, Alex (1999) "Social Theory Put to the Test of Politics: Pierre Bourdieu and Anthony Giddens," New Left Review 236: 77-102.

Canadian Securities Association (CSA) (2000) "CSA Provides Relief from Suitability Obligations," News Release. OSC Bulletin. 23: 2683.

Castells, Manuel (2000) The Information Age: Economy, Society and Culture, Vol. 1, The Rise of the Network Society, 2d ed. Malden, Mass.: Blackwell Publishers.

Coffee, John C., Jr. (1997) "Brave New World?: The Impact of the Internet on Modern Securities Regulation,” The Business Lawyer 52: 1195-233.

Condon, Mary (1998) Making Disclosure. Toronto: Univ. of Toronto Press.

Condon, Mary (2002) "Privatizing Pension Risk: Gender, Law and Financial Markets." In Privatization, Law and the Challenge of Feminism, edited by B. Cossman \& J. Fudge. Toronto: Univ. of Toronto Press.

Dean, Mitchell (1999) Governmentality: Power and Rule in Modern Society. London: Sage Publications.

Economy and Society (2001) Economy and Society 30(4): 399-564.

Ericson, Richard, and Kevin Haggerty (1997) Policing the Risk Society. Toronto: Univ. of Toronto Press.

Hawkins, Keith, and John Thomas (1989) Making Regulatory Policy. Pittsburgh: Univ. of Pittsburgh Press.

Hess, William L. (2000) "Republication of Proposed National Instruments 21-101, 23-101 and Related Documents (Marketplace Operation Rule and Trading Rules) - the 'Proposal.' Comment of the Canadian Venture Exchange, October 19. Toronto: $\begin{array}{llll}\text { Ontario } & \text { Securities } & \text { Commission. }\end{array}$ http://www.osc.gov.on.ca/en/Regulation/Rulemaking/Rules/ATS_comments_0007 28.html (accessed 8 July 2003).

Investment Dealers Association (IDA) (2000-1) Submission to the Canadian Securities Association on Relief from Suitability Requirements. 
Investors Dealers Association (IDA) (2001) Proposed By-Laws to Provide Trade-by Trade Relief from the Suitability Requirement OSC Bulletin. 24: 2923.

Kerbel, Jeff, and Catherine Wade (1999) "CSA Propose National Instrument to Regulate Alternative Trading Systems and Other Marketplaces,” Blake, Cassels and Graydon Securities Rules Alert 46 (July).

Kingford Smith, Dimity (2004) "Beyond the Rule of Law? Decentered Regulation in Online Investing”, Law \& Policy 26: 439-76.

Market Probe Canada (2000) The 2000 Canadian Shareowners Study. 29 May. Toronto: Toronto Stock Exchange.

Market Probe Canada (2002) The 2002 Canadian Shareowners Study. 23 August. Toronto: Toronto Stock Exchange.

Market Regulation Services (2001) “A message from Tom Atkinson, President \& CEO Market Regulation Services Inc.” News release, 7 December.

McCluskey, Martha T. (2002) "Rhetoric of Risk and the Redistribution of Social Insurance.” In Embracing Risk, edited by T. Baker \& J. Simon. Chicago: Univ. of Chicago Press.

O’Malley, Pat, Lorna Weir, and Clifford Shearing (1997) “Governmentality, Criticism, Politics," Economy and Society 26: 501-17.

Rose, Nikolas (1999) Powers of Freedom: Reframing Political Thought. Cambridge: Cambridge Univ. Press.

Scott, Colin (2001) “Analysing Regulatory Space: Fragmented Resources and Institutional Design," Public Law 2001: 329-53.

Stymeist, Barbara (2000) Re: Proposal to Regulate Alternative Trading Systems. Comment of the Toronto Stock Exchange, 19 October. Toronto: Ontario Securities Commission. Available at http://www.osc.gov.on.ca/en/Regulation/Rulemaking/ Rules/ATS_comments_000728.html (accessed 8 July 2003).

Tedesco, Theresa (2003) "TSX Offshoot Taking on Role of National Market 
Regulator." Financial Post, 3 March, FP6.

Valverde, Mariana, Ron Levi, and Dawn Moore (2003) Legal Knowledges of Risks. Report to the Law Commission of Canada, 2 June.

Wetston, Howard I. (1999) "Remarks to Canadian Investors Securitization Conference." 8-9 November, OSCB 22: 7093.

Wetston, Howard I. (2000) "Bringing Regulation Into Line With Reality: A Regulatory Perspective on a Changing World." Speech in Ottawa, 5 April. OSC Bulletin 23: 2875.

\section{CASES CITED}

Varcoe v Sterling (1992), 7 OR (3d) 204 (Ont Gen Div).

\section{LEGAL MATERIALS CITED}

Amendments to National Instrument 21-101 Marketplace Operation (2004) 27 OSCB 456.

Companion Policy 21-101CP (Marketplace Operation), (2001) 24 OSCB (Supp) 182. Companion Policy 23-101CP (Trading Rules), (2001) 24 OSCB (Supp) 206.

In the Matter of Market Regulation Services Inc. Recognition Order, (2002) 25 OSCB 924.

National Instrument 21-101 (Marketplace Operation), (2001) 24 OSCB (Supp) 136.

National Instrument 23-101 (Trading Rules), (2001) 24 OSCB (Supp) 198.

National Policy 11-201 (Delivery of Documents by Electronic Means), (1999) 22 OSCB 8163.

National Policy 47-201 (Trading Securities Using the Internet and Other Electronic Means), (2000) 22 OSCB 8062. 
National Policy 51-201 (Disclosure Standards), (2002) 25 OSCB 4492.

Notice of Commission Approval-Amendment to IDA Regulations 1300, 1800.5 and 1900.4 and IDA Policy No. 9 - Suitability Requirements, (2001) 24 OSCB 4513.

Notice of National Instruments, Companion Policies and Forms - Regulation of Marketplace and Trading, (2001) 24 OSCB (Supp) 85.

Notice of National Policy 11-201 (Delivery of Documents By Electronic Means), (1999) 22 OSCB 8156.

Notice of National Policy 51-201 (Disclosure Standards and Proposed Rescission of National Policy 40 Timely Disclosure), (2002) 25 OSCB 4459.

Notice of Proposed Amendments to National Instrument 21-101 Marketplace Operation and Companion Policy 21-101CP, (2003) 26 OSCB 4377.

Notice of Proposed National Instrument 33-103 Distribution Networks, (1997) 20 OSCB 6280.

Request for Comments (1999) National Policy 11-201 (Delivery of Documents by Electronic Means) 21 OSCB 7782.

Request for Comments (2001) Notice of Proposed National Policy 51-201 (Disclosure Standards and Proposed Rescission of National Policy 40 Timely Disclosure), (2001) 24 OSCB 3301.

Rule 31-502 (Proficiency Requirements), (2000) 23 OSCB 5658.

Rule 31-505 (Conditions of Registration), (1999) 22 OSCB 731. 